\title{
An Assessment of the Viability of Intergovernmental Relations in Enhancing Physical Developments in Enugu State of Nigeria.
}

\author{
Iyi, Edmund Amuezuoke (Ph.D)
}

\begin{abstract}
This study investigated the place of intergovernmental relations to revitalizing physical development efforts in Enugu State of Nigeria. It was with a view to finding out if the failure and/or abandonment of physical development projects is as a result of not maintaining intergovernmental relations. The sample frame of the study included consultation with officials in town planning matters, relevant ministries and parastatals, communities and other concerned international agencies. Proportionate stratified random sampling was used in selecting the various populations studied. Data collected were based on agencies involved in projects execution, the number of projects executed as well as the funds released for such projects for the period under study. Multiple regression analysis was used in the data analysis. The use of the model was to ascertain the magnitude and significance of relationship among given variables. The test was performed at $5 \%$ level of significance. The analysis revealed that intergovernmental relations on implementation of physical development projects do not facilitate achievement of objectives. The study advanced measures for efficiency chief of which is the institution of intergovernmental co-operations in the state at state, regional and local levels.
\end{abstract}

\section{Introduction}

For centuries of human existence on earth, man has put much effort into getting the best out of the earth. Much of the effort, which varies in form and intensity from one nation to another, revolves around two major issues, namely, improving the total national output so that the basic necessities of life, such as food, shelter and health services may be available to all; and providing a framework and environment that are conducive to the pursuit of higher goals at individual, corporate and national levels. Various theories and models have evolved over the years to tackle these issues. In Nigeria, for instance, efforts at inducing developments date back to the colonial period. Such efforts, since the Second World War, include the Ten-year Integrated Development Plan for 1946 - 1956, the Development Plans for the periods 1962 - 1968; 1970 - 1974; 1975 1980; 1981 - 1985 and the National Rolling Plans from 1990 to date. These efforts, according to Obialo (1999) are not really physical development planning experiences, but financial allocations for development projects. They were, however often articulated to achieve various laudable objectives for the overall interest of the citizenry.

The net problem associated with the development plans is non-realization of objectives within time frame. This has led to a number of projects remaining uncompleted years after the target period. In Enugu State, for example, most parts of the rural areas exhibit appreciable poverty, which result from lack of such basic infrastructure as roads, electricity, health and educational facilities. This is even when their provision had been provided for in the yearly budgets.

The problem addressed in this study, therefore, was that despite well articulated and goal oriented physical development plans specified in the yearly budgets of Enugu State, there is scarcely physical manifestation of the projects. Some of the projects are either commenced or abandoned or are never commences at all after approval. Few completed ones are never realized within target periods. There appears to be lack of adequate cooperation and coordination among stakeholders. It is the desire for progress and the needs to address this problem of development that has led to the urge to carryout regional physical development planning of the state alongside a model of interrelationships of relevant government agencies and other stakeholders.

It was hypothesized that intergovernmental relations on implementation of physical development projects, do not facilitate achievement of objectives. The intergovernmental relations were measured by the scale of involvement of different tiers of government. Implementation physical development projects were measured by the number of physical development projects implemented. Financial commitments for those physical development projects were measured by the percentages of the money released for those projects. The need for these hypotheses is to ascertain which model should be emphasized more in project execution. This was with a view to providing a clear basis for drawing a conclusion on the functioning of intergovernmental relations in Enugu State. 


\section{Review of Related Literature}

Intergovernmental relation (IGR) is defined as an important body of activities or interrelations occurring between governmental units of all types and levels within the Federal System (Anderson, 1960). Incidentally, the issue of interrelations between and among governments at international, national and local levels is an old one. Some of such interrelations come about in most informal ways while others are formal. In the formal sense, the interrelations are duly institutionalized through some forms of written treaties of differing magnitudes. For example, there have been treaties at international and other levels. Most of such treaties, however, according to Grenville (1973) have been concerned with economic and social questions.

Treaties include single state, bilateral and multilateral treaties. Bilateral treaties are those between two states (nations), while multi lateral treaties are concluded among three or more states (Grenville, 1973). One important observation made by Grenville was that, even though, there has been increase in the number and length of treaties due to increase in the number of sovereign nations, the general intentions of friendship and co-operation embedded in the language of the treaties are no guarantee of observance.

Ofoegbu (1980) worked on public international institutions and organizations and referred to them as inter-government organizations (IGOs). He observed that the organizations have grown both in number and in scope questions, as observed by Grenville, Ofoegbu gave a number of other spheres covered by the activities of the IGOs. They include food, military and security, health, culture and communication, judiciary and politics. Under economic sphere, there are such institutions as the International Monetary Fund (IMF), the United Nations Conference on Trade and Development (UNCTAD), and the various economic commissions for Africa and Latin America. Under food, there is the Food and Agriculture Organization (FAO), under health, there is the World Health Organization (WHO) and under culture, and communication, there are the United Nation Educational, Scientific and Cultural Organization (UNESCO) and the International Postal Union. Under judicial matters there is the International Court of Justice (ICJ), while under political sphere, there is the League of Nations.

Non of the International bodies as mentioned above, apart from the physical manifestation of implemented policies, is directly linked with planning of the physical environment. However, the lesson remains that such bodies form the brain child of interrelations among different world nations. However, more recently, and at a more localized arrangement, relative to the international sphere, there have been certain forms of IGRs directed at physical development. For example, in 2000, there was a bilateral conference on co-operative Research and Management of Binational Resources in the Upper San Pedro River Basin of Sonora and Arizona of Mexico and United States. The conference was to foster knowledge exchange and operation among residents, resource users, resource managers, and scientists in the Upper San Pedro River Basin (McElroy, 2000). In giving the background of the context, McElroy stated that San Pedro River Basins begins $40 \mathrm{~km}$ south of the United States - Mexico border in Sonora and flows north about $240 \mathrm{~km}$ to the Gila River in Arizona. The surface - water catchments for the San Pedro River drains on an area of $11,620 \mathrm{~km} 2$, of which approximately $16 \%$ is located in Mexico. During the conference, several elected officials from nearby communities, made brief comments about activities related to the San Pedro River, so that by sharing scientific research results with those at the local levels, the conference demonstrated how science can contribute to the formulation or rational resource management strategies.

There are two issues of interest in the binational conference as discussed above. One is that people of both sides of the Mexico and United States borders had a common goal. The goal was how best to reach an equitable means of preserving the unique habitat and the communities of the upper San Pedro River Basin. These issues are germane to IGRs arrangements irrespective of the scope of such arrangements.

In African, there have been different attempts made at emplacing intergovernmental relations for certain common goals. The latest move in this direction is the New Partnership for Africa's Development (NEPAD). NEPAD, according to Mashele (2007) is a holistic integrated sustainable development initiative for the economic and social revival of Africa involving a constructive partnership between the continent and the West. It was the belief of the African Heads of State that the attainment of the objectives of NEPAD, chief of which is to half poverty in Africa by 2015; would facilitate the creation of an African Economic Community by 2025.

NEPAD has a framework that comprises three segments which include (Mashele, 2007):

a. Establishing the necessary conditions for development: This includes ensuring that there is peace, security and good governance on the continent;

b. Identification of key priority sectors: This includes agriculture and food security, trade and market access, infrastructure development, human development including health and education, science and technology, culture, environment and tourism;

c. Resource Mobilization: This includes mobilizing domestic investment as well as seeking external technical and material support. 
After an overview of the implementation of NEPAD since the programme's inception, Mashele (2007) made two main observations. One is that NEPAD distinguishes itself from previous plans on the basis of its clearly elaborated leadership and implementation monitoring structures. The other one is the emphasis that NEPAD places on the need for African leaders to address issues of governance. These observations are central in the scheme of IGRs.

In Nigeria, there are forms of intergovernmental relations existent among the tiers of government. Nnamani (2003) stated that Nigeria operates a three tier system of government out of which certain systems of IGRs exist. The tiers include the federal government, the state government and the local government. The totality of all vertical and horizontal complex of formal and informal interactions among all these levels or tiers of government constitute the IGRs (Nnamani, 2003). Adamolekun (1989) gave the dimensions of the relationship as federal-state-local, federal-local, inter-state, state-local and inter-local, relations. The 1999 constitution of Nigeria spelt out the inter relations expected among the levels of government existent in Nigeria. The exclusive legislative list and the concurrent legislative list in the second schedule to the constitution provide the broad framework for federal-state and local relations, while the functions of the local government as spelt out in the fourth schedule indicates the major issues in state-local relations (Federal Republic of Nigeria, 1999).

\section{The Study Area}

Enugu State is one of the thirty six states into which the country, Nigeria, is currently divided. It came into existence out of the old Enugu State in 1996. The name Enugu is derived from Enugu City, the State Capital. It is made up of seventeen local government areas. It is represented by eleven elected members in the National Assembly, that is, three in the upper house (Senate) and eight in the lower house (House of Representatives). In the State House of Assembly, there are twenty four members representing the seventeen local government council areas of the state. There are three political zones in existence, namely, Enugu North, Enugu West, and Enugu East, and three corresponding urban centres, Nsukka, Oji-River and Enugu.

Furthermore, each government council area is a political unit that is divided into council wards. There are a total of three hundred and sixty wards in state during the Fourth Republic. Four tiers of government are in existence in the state, namely, international, Federal, State and Local. Several agencies of these governments are charged with physical planning development responsibilities in the State.

\section{Methodology}

Survey research method was adopted for the study. The study was carried out in 2012 and the sample frame included officials in town planning matters, relevant ministries and parastatals, the local government councils, communities and their leaders and other concerned international agencies. Proportionate stratified random sampling was used in selecting the various populations of study.

Questionnaire was administered alongside interviews to gather data on involvement of different tiers of government in implementation of projects, number of projects implemented and the finance released for the projects during the period under study, projects abandonment and the preferred option for management of intergovernmental relations. Multiple regression analysis was the statistical tool adopted for the analysis of the data. Descriptive analysis was also adopted for a group of generated data.

\section{Data Presentation and Analysis}

The number of other agencies that were involved in execution of projects by a particular agency during the period under review represented the scale of intergovernmental relations. The number of physical development projects executed during the period represented the scale of implementation of physical development projects. Average percentages of the amounts released for target projects during the period represented the scale of financial commitments. The observed frequencies in respect of the foregoing for the variable have been presented in Table 1.

Table 1:Observed Frequencies on IGRs, Physical Development Project and Financial Allocations.

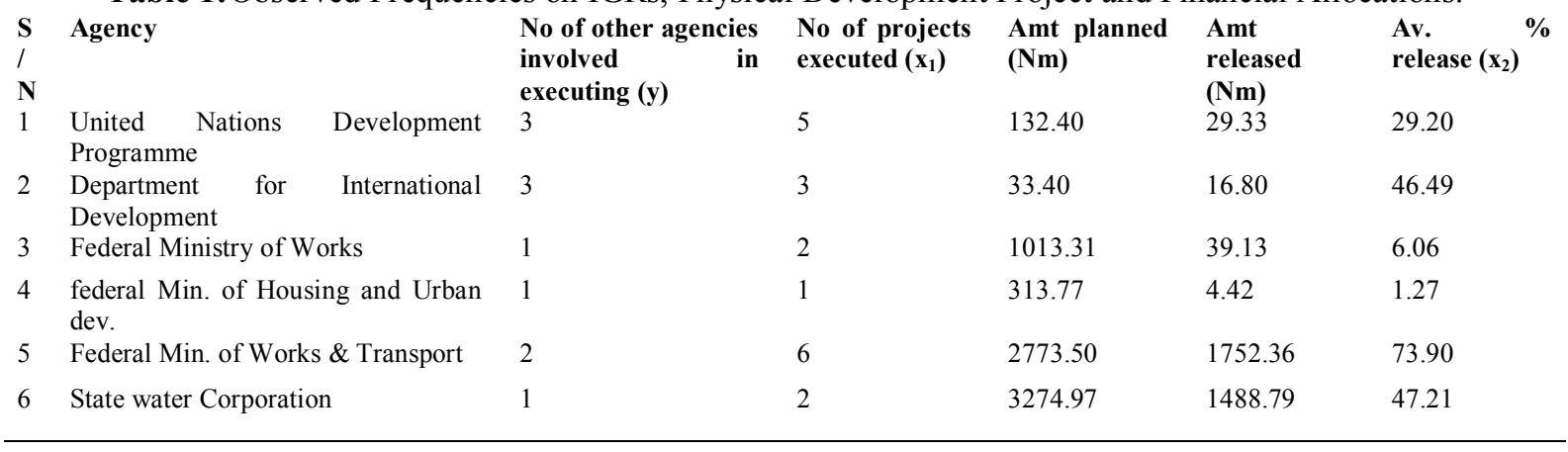




\begin{tabular}{|c|c|c|c|c|c|}
\hline State Rural Electrification Board & 1 & 6 & 962.96 & 5575.41 & 479.78 \\
\hline State Town Planning Department & 1 & 2 & 1229.00 & 1586.82 & 128.43 \\
\hline State Local Government Council & 2 & 19 & 18373.16 & 18373.16 & 100.00 \\
\hline Total & 15 & 46 & 28106.47 & 28866.22 & 101.37 \\
\hline
\end{tabular}

Source: Federal Ministry of Finance 2011; Enugu State of Nigeria (2007, 2010, 2011), Author's Research (2012).

Taking other agencies involved as the independent variable (y), then projects executed and percentage amounts released as dependent variables, $\mathrm{x}_{1}$ and $\mathrm{x}_{2}$ respectively, regression analysis and analysis variance (ANOVA) test was carried out. The result suggests that intergovernmental relations on implementation of physical development projects do not facilitate achievement of objectives.

The statistical model used has a revealing output as given below $\left(R=0.427, R^{2}=0.183\right.$, Standard Error $=$ $0.9041, \mathrm{~F}-$ Value $=0.671$ ).

From the data above, R2 (coefficient of determination) which shows the strength of relationship has a very low value. This shows that there was virtually no relationship between the variables. Furthermore, Fprobability, which is greater than the 0.05 confidence level proves that there exists no significance in the combination. The hypothesis was therefore, upheld.

In a section of the questionnaire, the opinions of the respondents were sought as to whether separate bodies should be constituted to oversee interrelations in the execution of physical development projects. The opinions have been shown in Table 2 .

Table 2: Opinion of Respondents in having separate Body for Management of Intergovernmental Relations

\section{S/N Respondent (Agency)}

Local Government Councils

Planning Authority Chief/Executive

Community Leaders

Town Planners

Other Related Professional

Total

Source: Author's Research, 2009

Total Nos.
17
17
215
20
17
286

Opinion
Yes
17
12
197
9
9
244

0.00

5.62

8.37

12.36

8.99

14.68

Table 2 indicates that out of 286 respondents, 244 or $85.32 \%$ were of the opinion that separate bodies should be set up to oversee intergovernmental relations in the state. 42 or $14.68 \%$ were of the opinion that there is no need for such.

\section{Discussion of Findings}

The discussion on the findings of the study hinged on the result of the hypothesis formulated for the study as well as the analysis of other groups of data. Attempt was made to bring the discussion to bear on the data presented and analyzed. The result has two principal revelations. Firstly, intergovernmental relationship among the agencies that are charged with the responsibilities of physical planning and development in Enugu state was not established. The second revelation is that there appeared no relation between the interrelationships among the physical agencies and fund releasing and utilization, can scarcely thrive where the utilization is as low as revealed for the target projects in the state. The cumulative percentage release of $101.37 \%$ did not agree with physical manifestation of projects as observed during the study. To this end, intergovernmental relations, which were supposed to hinge on the effectiveness of fund releasing and utilization, can scarcely thrive where the utilization is as low as revealed by this study. Intergovernmental relation among the agencies, therefore, can be made more functional when funds released for target projects are put into more effective use by such agencies. By so doing the advantages of good intergovernmental relations can be tapped. Such advantages, among others include:

(a) Concord of purpose among major stakeholders.

(b) Elimination of waste and duplication of labour and materials

(C) Existence of co operation rather than competition among physical planning and development agencies

(d) Sustainability of development programmes though succeeding governments

(e) Improvement of employment opportunities through enlarged physical development programmes.

(f) Raising the potential for tapping the economic base of the state

(g) Ensuring good utilization of the state political structure in initiating, funding and implementing target projects.

(h) Arousing the interest of the political office holders in delivery of physical development programmes

(i) Ensuring fair spread of physical development in the state. 
This can only be indicated by physical manifestation of such target projects. However, the study on existing intergovernmental relations in the state was not absolutely decisive. For example, for the fact that the international agencies concerned with physical development in Enugu state have specified areas of operation, it was difficult to deduce specific areas of interdependence. But since there appeared not to have been clearly espoused deliberate attempt at institutionalizing coordinating bodies for intergovernmental relations at any level of governance in Nigeria, not much efforts were found to be in line with the quest of this study in Enugu state. It is believed that a deliberate attempt at creating good intergovernmental relations among levels of government would bring about their concord of purpose. In this case, a positive and significant relationship would exist among them. This would, in turn, create a positive and significant relationship among them and effective utilization of funds released for physical development projects. In this case, an enabling environment would abound for maneuvering any one or two of these variables (intergovernmental relationships, funds and physical development projects) for efficiency in executing planned actions.

Another crucial dimension of the finding is that the rate at which project are initiated and abandoned was also found to be high. For example, Udi local government area, initiated a regional market at $9^{\text {th }}$ mile corner of Enugu state but this has been long abounded. Furthermore, some office blocks in the development centres created by the state government in 2004 are yet to be completed. At state level, such state roads such as UkeheAku-Nkpologu and Enugu-Mbu-Opi roads are yet to be completed after several years of commencement. This is an indication of lack of vertical intergovernmental relations. That is a situation where a project that was initiated and commenced by any existing administration lacked continuity by any succeeding administration. This phenomenon was more prevalent among the local government in the state. Furthermore the low pace of implementation of physical development programmes at local level negates the purpose of the third tier level of government. Ideally the creation and recreation of local government areas were aimed at facilitating development to reach the people at the grassroots, make rural life more meaningful and thus reduce urban rural gap. For the fact that, despite these local government creations, and the yearly state budget proposals to tackle physical development problems at all levels, some areas still exhibit lack of basic infrastructure, an interdependence of actions by stakeholders is desirable. In this case, a coordinating team would be mandated to keep tracks of major developments among planned programmes and respond accordingly for overall efficiency. If this is done, it will be in tune with Olumese's (1987) opinion that the existing administrative structure of our economy (i.e. Nigerian economy) should be modified to the maximum advantage to facilitate the integration of development planning for overall national development. The modification, to him should be along functional institutional arrangement or organizational structure, which emphasizes interrelationship among all government agencies.

However, for intergovernmental relations efforts to thrive there should be some enabling opportunities. It is on such enabling opportunities and how best to utilize them that planning for good intergovernmental relations among levels of government are based. Such opportunities for intergovernmental relations in Enugu State revolve around the presence of different levels of government, the resources available, the existing senatorial zones and political structure. Some of the international agencies in Enugu state deal specifically with physical developments. Examples include the United National Development programme (UNDP) and the Directorate for International Development (DFID). Federal agencies include such federal ministries as Works, Housing and Urban Development. The state government also has ministries and parastatals charge with physical development programmes. Examples include the Ministry of Works and Housing and Ministry of Public Utilities. The resource include human resource in form of labour availability: natural resources in forms of forest resources, solid mineral and tourist attractive areas: and man_date resources form of physical infrastructure. Further more, the existing senatorial zones form a form a strong base for functional regional arrangement since the political structure (local, state and national legislators and other officials) has already taken that shape. Any effort, therefore, emplacing any intergovernmental structure would thrive with minimal difficulty.

\section{Conclusion}

In this study, the level of and opportunities for intergovernmental approach to physical planning and development in Enugu state have been highlighted. The net finding is that, since there had not been any deliberate arrangement for intergovernmental relations among concerned agencies, the level of physical development has remained insignificant. That is, there is less vigour in interdependence among agencies involved in initiating, funding and implementing development programmes.

The study revealed that what would stand any intergovernmental arrangement in good stead in the state, especially in relation to the fiscal aspect, would be representative structure at federal, state and local levels. It is a structure whose potentials are virtually untapped. If the officials of the structure will be galvanized in accordance with the roles expected of those in service delivery and other stakeholders are brought together the goal of this study will be achieved as time goes on. As also gathered in the curse of the study, communities are willing to work together, local governments, ministries, parastatals, international and federal agencies in the 
state are willing to work together to enhance efficiency. Local governments, ministries, parastatals, international and federal agencies in the state are willing to work in partnership with others in executing physical development programmes.

The regional arrangement in Enugu state has potentials for direct allocation of resources to achieve desired regional, state and national objectives. This is so since such arrangement is a handiwork of the state government in which case the regions can be said to be essentially concerned with defining areas for intermediate level of government and administration.

All these issues raised have been carefully addressed by the recommendations of this study. As a major contribution, therefore, this study stands out as both descriptive and prescriptive documents for intergovernmental approach to physical planning and development.

\section{Recommendations}

Having assessed the level of intergovernmental relations and the opportunities thereof in physical planning and development in Enugu state, on one hand, and the need to constitute separate bodies to oversee the relation on the other hand, the following recommendations are made for efficiency.

a. Intergovernmental co-operation should be constituted at state, regional and local levels. At the state level, a coordinating team to be called the Enugu State Council on Intergovernmental Relations (ESCIR) will be set up. The heads of the various federal and state ministers and parastatals, as well as other international; agencies, involved in physical development should be representatives at ESCIR. At the regional level, Regional Council on Intergovernmental Relations (RCIR) will be set up. The local government council chairmen, the Town Planning Officers in charge of the Planning Authorities, federal and state legislators, appointed officials and other physical development personnel in each region will be representative at RCIR. At the local government level, Intergovernmental Relation Committee (IRC) will be set up. The head of departments concerned with physical development as well as community leaders should be representatives at IRC. Other non-governmental stake holders should be involved, as due, at each of the three levels discussed. The IRC will harmonize Rural Area Plan (RAP) and Local Plans (LP) as they affect the respective local government areas and in conformity with RCIR directives. The RCIR will harmonize the sub-regional plans (SRP) based on collated RAPs and LPs in each region and in conformity with ESCIR directives. ESCIR will harmonize the various objectives of the different ministries, parastatals, agencies, and come up with an integrated physical development plan. Intergovernmental relations at Enugu State will better take the form of regional plans (RP), Urban Plans (UP) and Subjects Plan (SP) because such arrangement will ensure project initiation at the grass root level.

b. The Enugu State Council on Intergovernmental Relations (ESCIR) should be made to ensure preparation of and judicious implementation of integrated physical development plans by making sure that the stakeholder co-operate in contributing resources (money, men and materials).

c. The existing three political zones of Enugu North, Enugu West and Enugu East should be adopted as the three regions of development planning, and using each of the three representative urban centers of Nsukka, Oji-River, and Enugu as regional centers. The RCIR in each region should keep track of the resources available to ensure optimum utilization and possible measures for growth.

d. Funding physical development programmes should be a collective responsibility of the three levels of government (Federal, State and Local) in the state. With the arrangements in (a) above, the interest of international agencies and other stakeholders will be aroused, in so far as there is apparent transparency in the scheme of operation. In this case, therefore, the coordinating team (ESCIR) should be made to ensure prompt and adequate funding from concerned stakeholders.

\section{References}

[1] Adamolekun, L. (1989). "The 1979 Constitution and Intergovernmental Relations” in Ekeh, P. P., Cole, P. D. and Olusanya, G. O. (eds). Nigerian Since Independence” The First 25 years. Vol. 5: Ibadan; Heinemann Educational Books (Nig.) Ltd.

[2] Anderson, W. (1960) Intergovernmental Relations in Review: Minneapolis:University of Minnesota Press.

[3] Enugu State of Nigeria (2009) Draft Estimates (Recurrent and Capital): Enugu; Government Printer.

[4] Enugu State of Nigeria (2010) Draft Estimates (Recurrent and Capital): Enugu; Government Printer.

[5] Enugu State of Nigeria (2011) Approved Budget (Recurrent and Capital): Benak Ventures

[6] Federal Government of Nigeria. Constitution of the Federal Republic of Nigeria, 1999. Lagos: Federal Government Printer

[7] Federal Ministry of Finance (2011) Detailed Breakdown of Allocation to Federal, State and Local Government

[8] Greenvile, J. A. S (1974) The Major International Treaties, 1914 - 1973: A History and Guide with Texts. Methuem and Co. Ltd.

[9] Mashele, P. (2007). "The New Partnership of Africa Development" Four years of Promising Attempt or Hollow Optimism?" 2000 - 2007 DGAP e.v. Alle Reachte Vorbehalten.

[10] McElroy, S. (2000). Divided Waters, Common Ground: Co-operative Research and Management of Binational Resources in the Upper San Pedro River Basin of Sonora and Arizona" San Pedro Conference Proceedings Pp. 1 - 13.

[11] Nnamani, C. I. (2003) Intergovernmental Relationship at a Glance: The Nigerian Situation. An unpublished MBA Dissertation, Department of Public Administration, ESUT.

[12] Obialo, D. C. (1999). Town and Country Planning of Nigeria. Owerri: Assumpta Printing and Publishing.

[13] Ofoegbu, R. (1980) Foundation Course in International Relations for African Universities. London: George Allen and UNWIN. 
[14] Okafor, R. (2003). "Institutional Arrangement for Unplanned Development of Enugu City" Paper Presented during the Three-Day Consultation of the sustainable Enugu Project (SEP) in Enugu. $26^{\text {th }}-28^{\text {th }}$ March.

[15] Olumese, C. E. (1987) "Strategy for Effective Rural Development: Institutional Approach and Intergovernmental Relationship" Journal of the Nigerian Institute of Town Planners (NITP): VIII and IX Lagos: NITP, Pp. $116-123$. 